УДК 004.418:528.94

\title{
ТЕХНОЛОГІЧНІ АСПЕКТИ ПІДГОТОВКИ КАРТОГРАФІЧНИХ МАТЕРІАЛІВ ДО ПУБЛІКАЦІЇ
}

๑ О. В. Попов, к.Т.н., Харківський національний університет радіоелектроніки, Харків, Україна

Изложены основные технологические особенности подготовки картографических материалов к публикации. Рассмотренная технология базируется на существующих в Украине достижениях в области технических и программных средств первичной обработки цифровых картографических материалов и некоторых зарубежных средствах, которые в нашем государстве достаточно популярны. Основными критериями избранной технологии являются показатели качества издания, затраты времени и финансов на его подготовку.

Sets out the main technological features of preparation of cartographic materials for publication. The technology considered is based on the existing achievements of Ukraine in the field of hardware and software for the primary processing of digital maps and some foreign media, which in our country is quite popular. The main criteria for the chosen technologies are indicators of the quality of publications, the cost of time and money on his training.

\section{Постановка проблеми}

Сучасні видання картографічних матеріалів є дуже популярними як у всьому світі, так і в нашій державі. Галузі їх застосування дуже різноманітні. Це видання для широкого вжитку: туристичні, навігаційні, інформаційно-довідкові. Більш вагомими є видання для органів державного управління, місцевого самоврядування та підприємств, що забезпечують життєдіяльність територій. Це демографічні, екологічні картографічні матеріали, земельний та майновий кадастри, схеми інженерних комунікацій, кадастри природних ресурсів та ін. Проб- лема їх оперативної підготовки до видання, особливо в нашій державі полягає у виборі, з точки зору витрати часу, фінансів та досягнутої якості оптимальної технології на усіх етапах обробки картографічної інформації.

\section{Аналіз попередніх} досліджень

Під час розроблення картографічних видань основну увагу звертають на використання сучасних картографічних даних, актуалізованих з використанням великомасштабних топокарт, сучасних аеро та космо-знімків та супровідної довідкової інформації. Створення та оперативна 
актуалізація просторових даних на основі даних дистанційного зондування землі (ДЗ3) є окремим науково-практичним завданням та вимагає розроблення методики підготовки топографічних основ та ортофотопланів, актуалізації та інтеграції картматеріалів на різних масштабних рівнях в єдиній системі координат. На сьогодні у світі розроблені та широко використовуються сучасні технічні та програмні засоби попередньої обробки картографічних матеріалів. До переліку найвідоміших виробників таких систем відносяться:

Фірма Leica, Heerburg (Швейцарія) продукує систему DVP (Didital Video Plotter). У 2000 р. фірма розділилася на три незалежні фірми, фотограмметричне та аерознімальне обладнання продукує фірма LH-Systems (Leica-Helava). Стереоспостереження ведуть за допомогою стереоскопа, прикріпленого до комп'ютера. Тип комп'ютера - PC.

Фірма LH-Systems (Швейцарія) розробила систему DPW (Digital Photogrammetric Workstation). Екран Tektronix або Stereo Graphics із глибиною зображення від 8 до 32 біт. Комп'ютер Spart-station з оперативною пам'яттю 5 Гбайт.

Фірма Zeiss Oberkochen (Німеччина) продукує систему PHOTODIS ST. Стереоспостереження відбуваються за допомогою частотних перемикань на рідких кристалах та «миші», яка просторово переміщує марку. Програмне забезпечення TOPOSURF дає змогу будувати цифрову модель місцевості, а пакет PHOTODIS OP - цифрові ортофотокарти.

Фірма MATRA (Франція) виробляє ЦФС TRASTER T10. Екран 1280×1028 пікселів, 24 біт глибини зображення. Спостереження здійснюється з використанням поляризації на рідких кристалах із частотою перемикання 120 коливань/с.

Фірма Intergraph, Huntsvilie (США) випускає систему Imagestation із монітором розміру $1664 \times 1248$ пікселів, 24 біт кольорової глибини зображення. Стереовимірювання відбуваються за допомогою рідких кристалів та інфрачервоного керування 3 частотою 120 Гц. В Україні повномасштабне застосування таких засобів з економічної точки зору не $є$ ефективним.

Однак, фірма «Геосистема», м. Вінниця (Україна) розробила ЦФС «Дельта», яка функціонує на базі стандартного комп'ютера PC, призначена для створення топографічних матеріалів, побудови ортофото, напівавтоматичного створення мереж фототріангуляції з прив'язкою до супутникових вимірювань системами GPS, ГЛОНАСС. Після 2010 р. для стереоспостереження випускається з поляризаційними окулярами, чи стереоскопами. Переміщення просторової марки відбувається за допомогою штурвалів, або «мишею». Система функціонує, використовуючи операційну систему Windows. Фірма випускає високоточні фотограмметричні сканери для сканування паперового чи фотоплівкового матеріалів. 


\section{Мета роботи}

Метою роботи $€$ розробка технології попередньої обробки картографічних матеріалів із застосуванням вітчизняних та зарубіжних технічних та програмних засобів для досягнення оптимальних показників цінаякість.

\section{Результати проведених досліджень}

Технологія створення цифрових топографічних планів призначена для виконання комплексу камеральних робіт, включаючи обробку растрових планшетів, отриманих шляхом сканування твердих оригіналів, фотограмметричну обробку матеріалів аерофотознімання, оцифровку планшетів і знімків, обробку цифрової картографічної інформації, зібраної різними методами, у тому числі й результатів польової зйомки, і одержання кінцевої продукції цифрового картографічного виробництва.

Описувана технологія призначена також для створення об'єктів і елементів інформаційного забезпечення цифрових топографічних планів (системи умовних знаків, семантики просторових об'єктів) 3 метою одержання й відновлення картографічних даних, а також створення моделей даних для розв'язку прикладних завдань.

Технологія створення цифрових топографічних планів повинна забезпечувати всі етапи виробництва цифрових планів шляхом організації відособлених технологічних циклів, які функціонально можуть виконуватися в рамках окремих підсистем. До таких підсистем ставляться:

- підсистема сканування й організації архіву растрових планшетів;

- підсистема фотограмметричного збору даних;

- підсистема зйомки на ортофотоплані;

- підсистема оцифровки планів;

- підсистема обробки цифрової картографічної інформації;

- підсистема видання картографічних матеріалів.

Технологія створення цифрових топографічних планів будується 3 використанням вітчизняного технічного та закордонного програмного забезпечення (Digitals, Arcgis) 3 ypaxyванням їх функціональних можливостей.

Основні технологічні етапи робіт

Вихідними даними для створення цифрових топографічних планів можуть бути:

1. Матеріали аерофотознімання та космознімання.

2. Планшети на твердій або плівковій основі.

3. Результати польових топографогеодезичних вимірів.

Технологія створення цифрових топографічних планів передбачає використання вихідних даних усіх типів, залежно від їхньої наявності, якість і ступеня їх актуальності. Можливо також комбінація вихідних даних.

Технологічний процес створення цифрових топографічних планів і баз даних у багатьох 
своїх етапах розділяється на паралельні технологічні етапи, які до певного моменту $€$ досить незалежними, щоб виконуватися паралельно й асинхронно. Виходячи із цього, нижче наведено опис технології з урахуванням точок синхронізації окремих паралельних процесів. У ре- зультаті виконання попередніх робіт вибирається необхідна система координат і в ній створюється математично обчислена картографічна основа проекту, по якій виконується монтаж багатошарової растрової топографічної основи на задану територію. Узагальнена схема

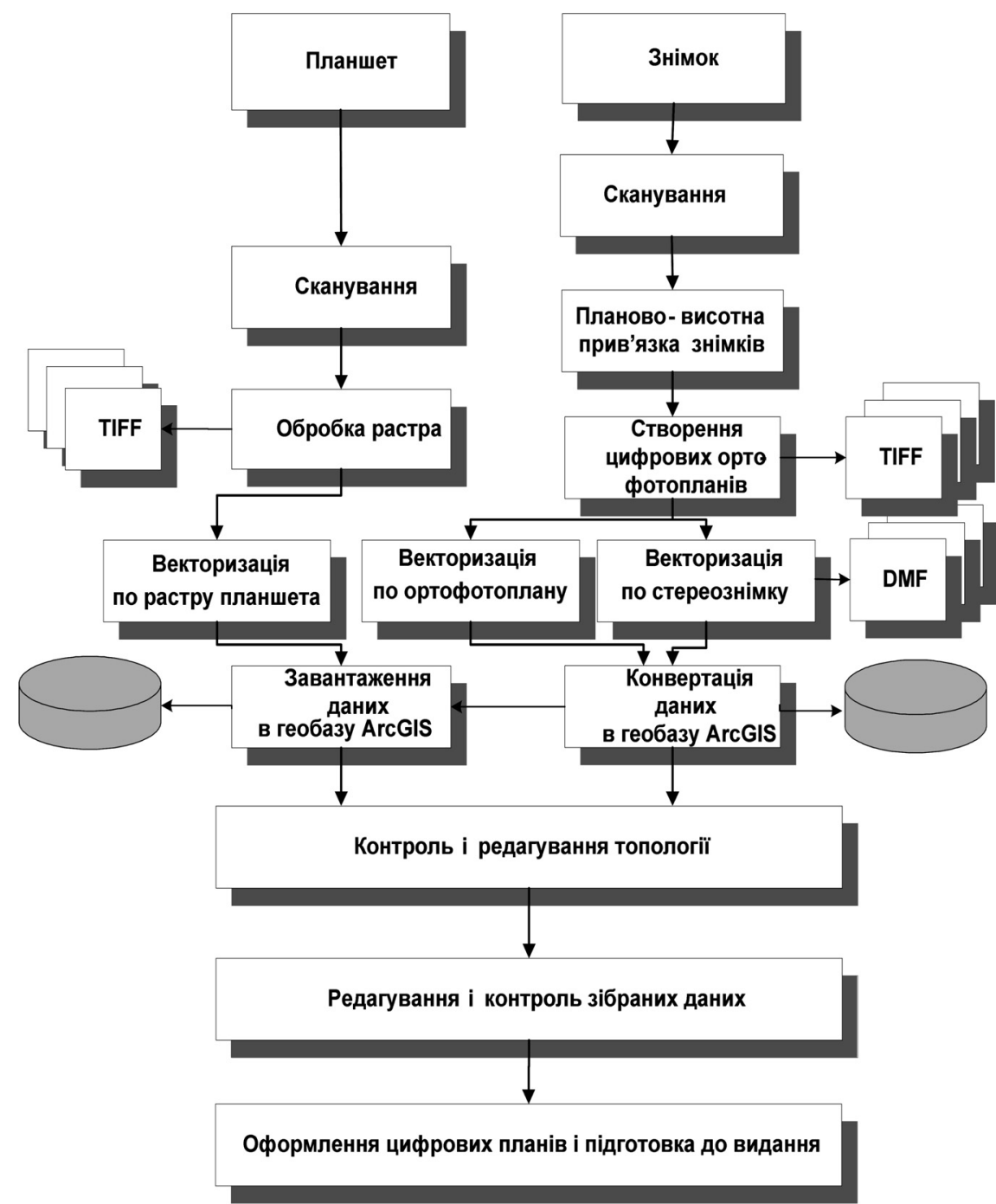

Схема технологічного процесу створення цифрових топографічних планів 
технологічного процесу створення цифрових топографічних планів наведено на рисунку.

Деякі технологічні етапи, у рамках даної технології, можуть бути пропущені в тому випадку, якщо вони виконувалися раніше (наприклад, створення ортофотопланів та ін.).

\section{Висновки}

Розроблена технологія з використанням вітчизняної фотограмметричної станції «Дельта» з програмним забезпеченням «Digitals» та програмного забезпечення Arcgis дозволяє створювати якісні цифрові плани 3 мінімальними фінансовими витратами.

Рецензент - О. В. Зоренко, к.т.н., доцент, НТУУ «КПІ»

Надійшла до редакції 19.06.13 